\title{
Commentary
}

\section{Concepts of Work in Marx, Durkheim, and Weber}

\section{Jan Ch. Karlsson'}

Professor of Organization, Department of Business, Languages and Social Sciences, Østfold University College, Norway

\section{Per Månson}

Professor Emeritus of Sociology, Department of Sociology and Work Science, Gothenburg University, Sweden

\section{DOI}

To be announced

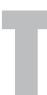

he extremely dramatic social transformation - called 'the great transformation' by Polanyi (1985) - that the full emergence of capitalism and industrialism meant in Europe led to the birth of modern social theory. The attention of the classics of the studies was taken up by trying to describe, understand, and explain this social change: What is actually going on? What does it mean to people and society? What does the development depend on? And what can be done about all social problems that this new society creates? Changes in working life are at the center of the analyses of social science from the start. Even when the analyses concern religion, culture, music, and the family, the emergence of a labor market, capitalist wage labor, and the concentration of production in large industries provide the reference point. Working life is the central arena of the classics of social theory. There is, however, no common definition of the key concept 'work' or 'labor' among the classical social scientists - as little as among current ones. Why is that?

We discuss the differences between Marx, Durkheim, and Weber, although we concentrate on the development of Marx's conceptualization of work, as he is the one among them to elaborate the analysis the most. We regard the differences in the light of the entity that their respective theory specifies (Elder-Vass, 2010, p. 16). We define a social theory as interrelated statements that tell us that a certain entity (thing, object, or process) exists in the world and often what this entity can do, that is which mechanisms it possesses (Karlsson \& Bergman, 2017, Ch. 1). Social theories are, then, arguments or series of interrelated arguments about something existing in the social world and commonly what social mechanisms are parts of the entity. The latter characteristic is especially important as mechanisms are what social scientists refer to in explanations. Theories are explanatory, although sometimes in the form of hypotheses, and what social science ultimately aims at is explaining the social world. Our analytical point of departure is that the defined entity of a theory also functions as a mechanism influencing its other concepts. We illustrate this claim by analyzing Marx's, Durkheim's, and Weber's differing ways of conceptualizing 'work' as an aspect of their respective theories

\footnotetext{
${ }^{1}$ Corresponding author: E-mail: jan.c.karlsson@hiof.no.
} 
pointing out quite dissimilar entities: Marx's basic entity is 'capital', which requires deep analyses of processes in working life, hence, his comprehensive theorization and conceptualizations of work and labor. Durkheim's entity is social cohesion, threats to it and how it can be organized; it is the importance of the division of labor, not labor itself that interests him. The social entity that fascinates Weber is the rationalization process, which does not require him to conceptualize work in itself as exhaustively, although he analyses working life intensely. We start with Marx.

\section{Marx's Concepts of Work}

The concept of work and labor is one of the most important ones in Marx's oeuvre. He used it in one way or another during his whole life, from his interest in the generic being of humans in his youth to his analysis of the economic laws of motion of the bourgeois society in Capital. It is, however, not exactly the same concept he uses, because he puts it in different contexts, and therefore, it refers to different social objects. In this part, we discuss how the same term - work or labor - acquired different meanings for Marx dependent on the level of abstraction and in which theoretical argumentation it is used.

\section{Work as a basic determination of human beings}

In Marx's youth, when he discussed Hegel's Philosophy of Right, he writes that it is 'The outstanding achievement of Hegel's Phänomenologie that Hegel grasps the essence of labor and comprehends objective man [...] as the outcome of man's own labor' (Marx, 1844, p. 66). In other words, Marx agrees with Hegel's anthropological definition of human beings as a result of their labor. This is even more obvious when Marx uses this determination of humans in a comparison with other animals. Man is, Marx writes, 'an active natural being', and like other animals, they 'have corporeal needs, are suffering, conditioned and limited creatures' (Marx, 1844, p. 69). However, there is one important difference between humans and other animals, namely that the humans produce their means of subsistence through their own work. In The German Ideology, Marx writes:

\footnotetext{
Man can be distinguished from animals by consciousness, by religion or anything else you like. They themselves begin to distinguish themselves from animals as soon as they begin to produce their means of subsistence, a step which is conditioned by their physical organisation. By producing their means of subsistence men are indirectly producing their actual material life. (Marx, 1987, p. 18)
}

In sum, this concept of work tells us that the human productive labor is what distinguishes human beings from other animals. Through their capacity to work, humans not only produce themselves individually, but through it they also produce their own history. So, because of their abstract capacity to work, humans transform themselves in accordance with the development of their work methods and their physical, psychological, and social needs. The ability of humans to work is therefore the basic force through which they change both the world around them and their own nature. This abstract notion of the labor of human beings is Marx's first concept of work. 


\section{Work as alienated labor}

However, this abstract concept presupposes a social reality where humans freely develop their capacity to produce both their subsistence and themselves. Another concept of work on a more concrete level is what Marx elaborates with the notion of alienated labor. In this analysis, Marx combines the abstract determination of work as a capability to express human nature through the labor process with the existing social forms of the production of their subsistence. Even if the overwhelming majority of the working people at the time Marx wrote this - in the 1840s in Western Europe - were peasants or craftsmen, he understood that a new way of producing was approaching rapidly. The basis for this new form of production was the relation between the private property owner of the means of production on the one hand and the 'free' laborers who were forced to sell their capacity to work to the owner of the means of production on the other hand. Hence, this is the basis for what Marx calls alienated labor.

According to Marx, the human capacity of creative production will in these circumstances be transformed into alienated labor, because this kind of labor is 'external to the worker, that is, it does not belong to his intrinsic nature; that in his work, therefore, he does not affirm himself but denies himself' (Marx, 1844, p. 30). Instead of being a part of the worker's self-creation it is, Marx says, forced labor. Therefore, this kind of work is

not the satisfaction of a need; it is merely a means to satisfy needs external to it. Its alien character emerges clearly in the fact that as soon as no physical or other compulsion exists, labour is shunned like the plague. As a result, the worker only feels free in his animal functions - eating, drinking, procreating, or the most of his dwelling and in dressing up, etc.; and in his human functions he no longer feels himself to be anything but an animal. What is animal becomes human and what is human becomes animal. (Marx, 1844, p. 30)

This alienation is expressed in several ways. The wage laborer is alienated from the result of his work, which now belongs to the capitalist. He is also alienated from the concrete working process and from other workers through the competition between the workers to get a salary. But, as we saw above, the workers are also alienated from their generic being, that is, in their work, they are not humans any more, but reduced to working animals. Lastly, Marx argues that wage labor alienates the individual from society and that therefore 'we must avoid postulating 'society' again as an abstraction vis-à-vis the individual. The individual is the social being. His manifestations of life [...] are therefore an expression and confirmation of social life.' (Marx 1844, p. 45)

\section{Work as the foundation of the history of societies}

If it is true that the basis of the life of human beings is their creative ability to work and produce themselves and the subsistence they need to survive, then this creative ability to work must also be the basis of the historical process of humankind. In this way, the concept of work is also the foundation of the history of societies. In the so-called materialistic conception of history, the concept of work is placed in the context of concepts such as the economic basis of society, its legal and political superstructure, the forces and 
relations of production, which together form special modes of production. However, it is obvious that Marx bases these societal concepts on the human capacity to work, for example, when he writes that the basic

premise of all human existence and, therefore, of all history [is] that men must be in a position to live in order to be able to 'make history'. But life involves before everything else eating and drinking, a habitation, clothing and many other things. The first historical act is thus the production of the means to satisfy these needs. (Marx, 1987, pp. 17-18)

\section{Work as labor power in the capitalist system}

Also in Marx's theory of capitalism, the concept of work has a very important place. However, it is much more complicated in this part of the theory than before, and there are some prominent distinctions that sustain the basic theoretical framework. The foundation of the production in the capitalist system is the production of commodities to be brought to and sold on the market. After Marx has discussed the double nature of commodities - they have both use value and exchange value - he says that the owner of money who wants to start to produce

must be so lucky as to find [...] in the market a commodity, whose use-value possesses the peculiar property of being a source of value, whose actual consumption, therefore, is itself an embodiment of labour, and, consequently, a creation of value. The possessor of money does find on the market such a special commodity in capacity for labour or labour-power.

(Marx, 1887, p. 119)

In this theory, therefore, the capacity of human beings to work has two aspects. The first is concrete labor, that is, the concrete work a person does who produces something, a car, a dress, a bottle of wine, or something else. This work is behind the commodity's use value, to drive, to dress, or to drink. The second aspect is abstract labor, which is the amount of time that a person has worked on some object. It is this abstract labor that makes different commodities exchangeable with each other. When we exchange commodities, or use money to pay or get paid, we therefore exchange certain amounts of human labor. Therefore, there is no basic difference in the capitalist system between a commodity that is produced in a factory and the special commodity that is a part of the human being: the capacity to work. Both are commodities that are produced, and both have use value and exchange value. The labor power's exchange value is equivalent to the wage the laborers get for selling their capacity to work. Then, the laborers use this wage to buy subsistence to produce the next day's labor power. The use value of labor power is the concrete labor a worker does while working:

On the one hand all labour is, speaking physiologically, expenditure of human labour power, and in its character of identical abstract human labour, it creates and forms the value of commodities. On the other hand, all labour is the expenditure of human labour power in a special form and with a definite aim, and in this, its character of concrete useful labour, it produces use values. (Marx, 1887, p. 33) 
Marx uses this difference between the result of the labor power's use value, that is, the product that the concrete labor will generate, and exchange value, that is, the abstract labor time the producers has used to produce the goods, to explain the capitalist's profit. The difference between how much value a worker's labor power can produce during, for example, a day, and his or her exchange value - that is, the wage during that day - Marx calls surplus value. The surplus value is based on this difference, and from this surplus value, the company's profit emerges.

Behind the surplus value, there is another concept of work in the theory of capital: the concept of surplus labor. Marx uses this concept to show that the surplus value in the capitalist system is just another form of surplus labor. In slave societies and in feudal societies, the slaves and the peasants had to work more than to produce subsistence for themselves because the slave owner and the noble also lived on their labor. So,

capital has not invented surplus labour. Wherever a part of society possesses the monopoly of the means of production, the labourer, free or not free, must add to the working-time necessary for his own maintenance an extra working-time in order to produce the means of subsistence for the owners of the means of production. (Marx, 1887, p. 164)

This means that in all class societies, there is some form of surplus labor, but the forms will vary depending on the form that labor takes in that society.

In this context, Marx makes an interesting point about the development of the concept of abstract labor. He says that it is only in a capitalist economy that one can 'discover' the abstract nature of labor, because the capitalist does not care what kind of work is performed, it is only the amount of labor that is behind the value of the produced commodity. Marx gives the credit for this discovery to Adam Smith, who, according to Marx, 'rejected all restrictions with regard to the activity that produces wealth - for him it was labour as such, neither manufacturing, nor commercial, nor agricultural labour, but all types of labour' (Marx, 1859). Therefore, Smith was the first to understand that human labor is behind the value that is produced in capitalist economy. Marx also makes a methodological point of the relation between the historical development and the abstraction process:

The example of labour strikingly demonstrates how even the most abstract categories, despite their validity in all epochs - precisely because they are abstractions - are equally a product of historical conditions even in the specific form of abstractions, and they retain their full validity only for and within the framework of these conditions. (Marx, 1859, section 3)

An obvious example of Marx contextualizing his concept of work is when he discusses the difference between productive and unproductive labor. Here, Marx defines the difference from the point of view of capitalist production:

Productive labour [...] reproduces not only this part of the capital (or the value of its own labour-power), but in addition produces surplus-value for the capitalist. [...] Only that wage-labour is productive which produces capital. (Marx, 1863, p. 1) 
It is only that work which produces value for the worker's wage and surplus value to the capitalist that, from the point of view of the capitalist system, can be regarded as productive work. All work in society which does not produce value for capital must, according to this view, be considered unproductive. It is not the work in itself or how valuable its results are for people or society that makes work productive or unproductive. It is only work that contributes to increasing capital that is productive in capitalist society, according to this theory.

\section{Conclusion}

One conclusion from this overview of Marx's concepts of work is that he changed his conceptualization depending on in which context of working life it was discussed. However, there seems to be continuity between the young Marx's discussion of work as a free and creative activity that differentiates human beings from other animals, over the concept of alienated labor and the idea that human labor is the basis of the historical process, to the mature Marx's discussion of the labor power of the wage laborer. The difference between these various concepts of work is that they are situated at different levels of abstraction. The first concept, work as a free, creative activity, is an abstract anthropological determination of human beings. In the materialistic conception of history, Marx makes this general determination the foundation of the historical process, which means that 'men make their own history' as creative agents, but not as they please, 'not under self-selected circumstances, but under circumstances existing already, given and transmitted from the past'. (Marx, 1852, p. 5)

In the discussion of alienated labor, Marx analyses what will happen with the anthropological determination of human beings in a society where work is performed by wage laborers. In his theory about the 'laws of motion' of the capitalist system, he uses several conceptions of work, from the transformation of work to wage labor, over the valorization of the concrete labor to abstract labor and the relations between surplus labor and surplus value, to the concepts of productive and unproductive labor from the perspective of the expansion of capital. Therefore, one can say that the concept of work is both very important in many of Marx's texts, and that there are dissimilar but closely related concepts in his theory of work. It is also important to note that Marx's basic goal with his own theoretical and practical work was to contribute to what he called 'the emancipation of work' (e.g., in Marx, 1974, p. 82), because in a society where one part of its inhabitants is subordinated to another part, work can never be a 'free, creative activity'. It was Marx's vision about the post-capitalist society that in it the human capacity to work would at last be liberated from compulsion. This life-long theorizing of work is an effect of the mechanism of the concept of capital being the entity driving his theoretical development.

\section{Durkheim's Lack of a Concept of Work}

In the theory presented in Émile Durkheim's (1964 [1893]) The Division of Labor in Society the entity is not labor but social cohesion. In view of the phrase 'division of labor', Durkheim was mainly interested in the concept of division - that tasks are 
divided - rather than the concept of labor - what is divided. In spite of the title of the book, he does not discuss working life until the last part. We seek in vain for a definition or even a more detailed discussion of the central concept of labor or work (Durkheim 1930 [1893] uses only one term, travail, but it is translated with both English terms). Durkheim sees the division of labor as a general biological process, starting with the introduction of life itself on Earth. The social division of labor is merely a special case of this process, which 'governs the entire world' (1964: 41). The reason he analyses the division of labor is that in society it has the moral function of creating social solidarity. He mentions several different forms of work, such as domestic, economic, scientific, and artistic work, but without any internal relation between them. We do not learn what makes them types of work. At the same time, the division of labor plays an essential role in Durkheim's theory.

The important distinctions are made between types of solidarity in types of societies and in order to understand the position of the division of labor in Durkheim's theory we need to look at them. The most important distinction is that between two types of solidarity: mechanical and organic. As law expresses morality, Durkheim applies types of law as measures of the different forms of solidarity. Where penal law expressed in repressive sanctions, which inflicts harm in one way or another on those offending it, is widespread there is mechanical solidarity. Contract law with its restitutive sanctions, which tries to bring things back to what they were before the offence, is instead extensive where there is organic solidarity. Further, mechanical solidarity is based on likeness between its members, while organic solidarity comes from differences between them. Each corresponds to a certain form of society, namely the mechanical solidarity of segmental societies and the organic solidarity of advanced societies. We are thereby getting closer to the division of labor. In mechanical solidarity, individuals are subjected to the same values and norms in a 'collective conscience'. Members of groups are incorporated in them in such a strong way that one cannot claim that there are individuals; every offence against the norms of the collective conscience is punished severely. Individuals are fitted into the group in a mechanical way, that is naturally and without reflection. The more advanced society has, however, a quite different character in this basic regard. The development of the division of labor leads to organic solidarity, which in contrast to the mechanical one is based on differences between people. New and strongly specialized occupations emerge and many other social functions are differentiated from each other. Hereby, the individual emerges through people in their specialization being divided from other people - but at the same time the individuals become dependent on each other. Social solidarity does not build any longer on the common and strictly guarded moral of mechanical solidarity, but is based on the dependence of individuals on one another in a system of specialized functions, which has arisen with the division of labor of advanced societies - organic solidarity.

Even if the moral function of the division of labor is to fill the social need of solidarity in civilization, this is not the reason for its development. In explaining the division of labor, Durkheim employs the concepts of density and volume of a population. Older types of societies are segmented - they are built by a number of structural segments without much internal connection. In the development toward advanced societies, more and more segments are opened up, resulting in increasing relations between people. From this follows growing moral density in society accompanied by material density in the form of means of communication. More moral and material density lead in their 
turn to an amassed division of labor. A second cause is growing social volume, as the density process incorporates more and more people in society. A quite intriguing question in connection with this explanation is raised by Dag Østerberg (1974, p. 58), who points out that it seems to be taken directly from a passage in Marx's Capital without Durkheim mentioning this. Marx (1974, p. 245; our emphases) says in his analysis of the division of labor in manufacture:

Just as a certain number of simultaneously employed laborers are the material prerequisites for division of labor in manufacture, so are the number and density of the population, which here correspond to the agglomeration in one workshop, a necessary condition for the division of labor in society. Nevertheless, this density is more or less relative. A relatively thinly populated country, with well-developed means of communication, has a denser population than a more numerously populated country, with badly-developed means of communication.

In contrast to many of his contemporaries as well as predecessors, however, Durkheim does not regard the growing division of labor as leading to decomposition of the social order; instead, he claims that it gives rise to a new social order with a different kind of community bearing the stamp of organic solidarity.

Then, in the third part of the book, he discusses abnormal or pathological forms of division of labor in contemporary France. These are forms that exist but do not result in social solidarity. They can all be found in working life, as does Durkheim's suggested solution. It is not until here that work really enters the picture. One of the abnormal forms is the anomic division of labor, of which a first type is economic crises; a second is the conflict between capital and labor - which Durkheim regards as a deviation or social sickness, but which Marx sees as the central inherent trait of capitalism; and a third is the increasing specialization of scientific work. Behind this pathology lie rules that have developed outside the division of labor and which have made it difficult to understand and foresee. Organic solidarity can only come about when the rules emerge from within the division of labor itself.

Another abnormal form is the forced division of labor, which occurs when there are class struggles, resulting in individuals' positions in the social division of labor not being in accordance with their natural abilities. 'In short', Durkheim says (1964, p. 377), 'labor is divided spontaneously only if society is constituted in such a way that social inequalities exactly express natural inequalities.' When people are forced into positions that are unnatural for them, the division of labor cannot result in organic solidarity. Finally, there is an abnormal form that Durkheim does not name, but which we can call 'discontinuous work' (cf. 1964, p. 392) and which means that employees do not have enough to do at their workplaces. This leads to too few contacts, something that diminishes the possibilities for organic solidarity.

Durkheim also puts forward a suggestion - mainly in the famous 'Preface to the second edition' - to solve the problems created by the abnormal division of labor. He explains its background like this $(1964$, p. 5):

if anomy is an evil, it is above all because society suffers from it, being unable to live without cohesion and regularity. A moral or juridical regulation essentially expresses, then, social needs that society alone can feel; it rests in a state of opinion and opinion is a collective 
thing, produced by collective elaboration. For anomy to end, there must then exist, or be formed, a group which can constitute the system of rules actually needed.

This group would be made up of corporations of both workers and capitalists. Corporations would have the necessary intimate knowledge of working life - and life outside work - and at the same time the authority to uphold the natural rules produced inside the division of labor. Thereby, the organic solidarity, which now is prevented by abnormal division of labor, would grow.

Compared to the analysis in The Division of Labor in Society, Durkheim (1992) discusses labor a little bit more explicitly, although in a critical approach, in his lectures on professional ethics and civil morals, first delivered in 1890. In connection with his analysis of the phenomenon of property and the origin of ownership, he polemicizes against what he calls 'the theory of labor'. In his description, this is a somewhat simplified version of the labor theory of value as expressed by the classical economists, claiming that property rests on work. This theory, he says (1992, p. 125), cannot at all explain how property 'has become what it is and how we can account for the form it has in present-day societies'. In one polemical formulation, he comes as close to a definition of work as he gets (1992, pp. 154-175): 'Labour in itself [...] consists exclusively in a certain expenditure of muscular energy; it cannot, then, create things'. In accordance with his theory of religion, property is instead explained by the societal opinion by being regarded as holy.

In sum: Durkheim does not need to define the concept of work because the entity of his theory is social cohesion. This makes the division of tasks between people more important than that it is work that is divided. Further, when he analyzes working life in connection with the discussion of pathological forms of division of labor, he can be satisfied with taking the concept for granted: work is wage labor. The entity of his theorizing does not make a more definite conceptualization of work or labor necessary. When he later gets closer to a definition, it is only to criticize the 'theory of labor' as an explanation of the existence of property in society.

\section{Weber's Limited Conceptualizations of Work}

Max Weber, like Marx, put forward more than one concept of work. The first one appears in The Protestant Ethic and the Spirit of Capitalism, the second and third in Economy and Society and they are not compatible - which is an effect of work not being the entity of his theoretical endeavors - a position instead taken by the historical rationalization process. To start with the first concept of work, Weber constructs an ideal type of the spirit of capitalism through the writings of Benjamin Franklin, who in his Advice to a Young Tradesman expressed this spirit 'in almost classical purity' as an ethos of this economic system (Weber, 1970, p. 48; [1904-1905]). There are several forms of capitalism in history, but this is the spirit of the specific modern form developed in the West and which is characterized by rational organization of - at least formally - free labor. These ideas emphasize that the individual has a duty to increase the capital that he or she possesses and not waste resources on a life in luxury. 'Time is money', Franklin says. People should live their lives according to these maxims; it is an ethos for how to spend your entire time in modern capitalism constantly, rationally, and systematically 
seeking profit. Life in capitalist culture should be a duty, a calling to labor for the sake of labor itself - a calling in the sense of a well-defined domain to work in, a task defining one's life. This ascetic trait is central to the spirit of capitalism of the Western world and has never been seen before in any other social system.

The term 'calling' is of importance here, but the translator, Talcott Parsons, had some trouble with it. Weber's term is Beruf and Parsons says that he sometimes translates it as 'profession' and sometimes as 'calling', depending on context (1970, p. 194, n. 11). It is worth noting this when reflecting on Weber's concepts of work. (Weber himself made rather extensive comments on the etymology and development of the meaning of the word Beruf, 1970, pp. 204-211, n. 1-3). We will come back to this point in connection with his second conceptualization of work.

Now, Weber's interest does not lie in the spirit of modern capitalism in itself, but in its connections to religious ideas, especially Protestantism. How can the emergence of this spirit of 'a calling and the devotion to labour in the calling' $(1970$, p. 78) be explained historically? Here, Weber dismisses what he calls 'the more naïve historical materialism' (1970, p. 55, cf. p. 75) of base and superstructure - it is unclear whether he alludes to Marx or some of his followers. At the same time, he declares his own position as more sophisticated than being the opposite of naive historical materialism:

we have no intention whatever of maintaining such a foolish and doctrinaire thesis as that the spirit of capitalism (...) could only have arisen as the result of certain effects of the Reformation, or even that capitalism as an economic system is a creation of the Reformation.

Instead, he uses terms such as 'correlation', 'closely connected', and an 'intimate relationship' for the link between the spirit of capitalism and the Protestant ethic.

Aiding this comparison, he constructs another ideal type - this time, of course, of the Protestant ethic. This is based on the teachings of Jean Calvin but at the kernel of it lies a specific ideal type of work constructed on the theology of the English Puritan Richard Baxter. Beside Calvin, Baxter plays the same role for the pure type of the Protestant ethic as Franklin does for the one of the spirit of capitalism. Baxter preached the importance of 'hard continuous bodily or mental labour', Weber (1970, p. 158) says, and there are two different motives that together lead to this position. One is the idea that work has an ascetic effect through being a shield against a sinful life; the other is that one should work for the glory of God. Not wanting to work in a disciplined way is an indication that one stands outside God's grace. No one is freed from this command it is without exception (1970, pp. 159-160; 1934, p. 172):

Even the wealthy shall not eat without working [arbeiten], for even though they do not need to labour to support their own needs, there is God's commandment which they, like the poor, must obey. For everyone without exception God's Providence has prepared a calling [Beruf], which he should profess and in which he should labour. And this calling is (...) God's commandment to the individual to work for the divine glory.

In this analysis, it is obvious that the term Beruf as calling has a strong moral connotation. In Economy and Society (1978 [1919-1920]), the term Beruf is, however, used without this moral sense - or as Weber (1970, p. 205) says, in an 'ethically colourless' way. It is also translated as 'occupation', not 'profession' or 'calling'. This is the second 
conceptualization concerning working life. The term, Weber (1978, p. 140) says, 'will be applied to the mode of specialization, specification, and combination of the functions of an individual so far as it constitutes for him the basis of continuous opportunity for income or earnings'. He then goes on to discuss diverse variants of occupational structures in different times. Weber uses, then, the same term - Beruf - for two different concepts, something which the translators have observed through expressing it with calling and occupation, respectively. Still, it might be a bit confusing if it goes unnoticed.

A third concept of work can also be found in Economy and Society. It is presented as part of Weber's development of a specifically sociological, as opposed to economic, terminology for analyses of the economy. At the same time, the concept of work is only a minor part of this conceptual constellation. In the overwhelming multitude of concepts, typologies and definitions within the economic sociology, the concept of work plays an insignificant role. Let us follow some of the threads involved in the concept. To begin with, Weber defines the sociological categories of economic action. In this series of conceptualizations, we have first economically oriented action, which means that the actor gives the act the meaning that it satisfies a desire for utilities; then economic action, defined as 'any peaceful exercise of an actor's control over resources which is in its main impulse oriented towards economic ends' (1978, p. 63); further, rational economic action which involves deliberate planning (instrumental rationality). Another conceptual trait involved in the concept of work is a distinction between economy and technology. Technique involves the means to reach the goals of an action while economic action is concerned with the ends of an action. 'Services' are 'Utilities derived from a human source, so far as this source consists in active conduct' (1978, p. 68). There is also the element that there is a higher probability that managerial actions in economically oriented actions are rational than other actions in organizations. Finally, there are three types of division of labor, technical, economic, and social, and the definition of 'labor' is part of the technical, not the social, one.

Thereby, we can go to the formal definition of work: 'Human services [Leistungen] for economic purposes may be distinguished as (a) 'managerial', or (b) oriented to the instructions of a managerial agency. The latter type will be called 'labor' [Arbeit]' (1978, p. 114; 2013, p. 296). This definition turns out, however, to be a bit ambivalent as Weber immediately adds:

It goes without saying that the managerial activity constitutes 'labor' in the most definite sense if labor is taken to mean the expenditure of time and effort as such. The use of the term 'labor' in the sense defined above, as something distinct from managerial activity, has, however, come to be generally accepted for social reasons, and this usage will be followed in the present discussion. For more general purposes, the terms 'services' or 'work' will be used. (1978, p. 114)

This leads Weber to use phrases such as 'labor or other work' and 'management and ordinary labor' more than just 'labor' or 'work' in the further argumentation.

In sum, we find that Weber uses three different concepts of work in his analyses. In The Protestant Ethic and the Spirit of Capitalism work (Beruf) is a calling as part of the ideal type of the Protestant Puritanism as well as in that of the spirit of modern capitalism. It is thereby not a general concept but adjusted to the requirements of these ideal types, and thereby rather limited in scope. In Economy and Society, the term Beruf has a 
quite different meaning, namely occupation, which is an even more limited sense. A third conceptualization can also be found in Economy and Society, in which work is as limited through being demarcated as non-managerial actions - and often traditional rather than rational in orientation. In the pure type of Puritanism, everyone without exception should work in a calling. Here, labor embraces managers as well as workers, it is rational and it is carried over into capitalism. In the more general sociological analysis of the economy, on the other hand, managers do not work but their actions are rational, while those who work are oriented to management's rational orders but are themselves more traditionalistic. There are rifts rather than continuity between Weber's three concepts of work, however limited each one of them is. The reason for this is that the entity of his theoretical endeavors is not work or even working life as such, but the rationalization process running through all of history.

\section{Conclusion}

Karl Marx, Émile Durkheim, and Max Weber all formulated their theories in relation to the world-shattering transformations of working life through the industrial and capitalist revolutions. Their common denomination is that analyses of the development of working life are central to them. The broad divergences between their theories within this field are well-known, but we pay attention to the special differences in their ways of theorizing the concept of work. Marx struggled continuously with several conceptions of work at different levels of abstraction, from work as a free and creative activity that makes up the dividing quality between human beings and other animals, over the alienation in wage labor to the decisive role of work in the secret of the commodity and of profit. Durkheim did not discuss the concept of work at all, despite the importance of the division of labor in his theory. It is the phenomenon of division, not labor, that is important in relation to the development from mechanical to organic solidarity. Not even in his analyses of the anomic division of labor and its remedies - located in working life - does he consider the concept of work itself. Instead, he seems to tacitly agree to the common idea in sociology that work equals wage labor. In his book on Professional Ethics and Civil Morals, he is also extremely critical of what he calls the theory of labor. Weber, finally, formulated three rather limited and partly contradictory concepts of work. One, termed Beruf, is part of the ideal type of the Protestant work ethic, expressing that everyone has to work in a disciplined way in a calling because such is God's will. The second, also termed Beruf, is an occupation in the division of labor. And the third makes up a small part of the enormous set of concepts in his economic sociology, defining work as human services for economic purposes that are directed toward management dispositions.

We suggest that the differences we have pointed out between these three classics of social theory can be explained by the diverging entities that their respective theory defines. The entities function as mechanisms for the treatment of the concept of work. Our point of departure is that social theories define entities existing in the social world. For Marx capital, its development and expressions, is this entity which makes work a central concept in his theorizing. In Weber's theorizing the rationalization process through history is the entity, leaving only limited room for the concept of work. And the entity of Durkheim's theory is social integration and solidarity, in which the division of tasks plays the decisive role while what is divided - called work in a taken for granted sense - is unimportant.

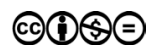


We have tried to demonstrate that the perspective of the conceptualization of entities of theories as mechanisms for actualizing other concepts directs us toward noticing traits in theories not quite observed before: Marx's continuity in conceptualizing work at different levels of abstraction; Durkheim's lack of a real concept of work as he first is uninterested in what in the division of labor is divided and then tacitly accepts the formula work is wage labor - all due to the entity of his theory being social cohesion; and Weber's three limited and contradictory work concepts, because each play different theoretical roles in separate analyses of the rationalization process, which is the basic entity of his theory.

\section{References}

Durkheim, É. (1930 [1893]). De la division du travail social. (On the Division of Labor in Society) Paris: Presses Universitaire de France.

Durkheim, É. (1951 [1897]). Suicide. New York: Free Press.

Durkheim, É. (1964 [1893]). The Division of Labor in Society. New York: Free Press.

Durkheim, É. (1992). Professional Ethics and Civil Morals. London: Routledge.

Elder-Vass, D. (2010). The Causal Power of Social Structures. Emergence, Structure and Agency. Cambridge: Cambridge University Press. doi: http://dx.doi.org/10.1017/ CB09780511761720.

Karlsson, J. C. \& Bergman, A. (2017). Methods for Social Theory. Analytical Tools for Theorizing and Writing. London: Routledge.

Marx, K. (1844). The Economic-Philosophical Manuscripts of 1844. https://www.marxists. org/archive/marx/works/download/pdf/Economic-Philosophic-Manuscripts-1844.pdf.

Marx, K. (1852). The Eighteenth Brumaire of Louise Bonaparte. https://www.marxists.org/ archive/marx/works/download/pdf/18th-Brumaire.pdf.

Marx, K. (1859) Introduction to a Critique of Political Economy. https://www.marxists.org/ archive/marx/works/1859/critique-pol-economy/appx1.htm.

Marx, K. (1963). Theories of Surplus Value. CHAPTER IV Theories of Productive and Unproductive Labour. https://www.marxists.org/archive/marx/works/1863/theories-surplus-value/ch04.htm.

Marx, K. (1974 [1867]). Capital I. https://www.marxists.org/archive/marx/works/download/ pdf/Capital-Volume-I.pdf.

Marx, K. The German Ideology, in Marx, Engels, Lenin (1987). On Historical Materialism. Moscow: Progress Publishers.

Marx, K. (1974 [1864]). The First International and After. Harmondsworth, Middlesex: Penguin.

Østerberg, D. (1974). Emile Durkheims samfunnslære. (The Social Teachings of Emile Durkheim) Oslo: Pax.

Polanyi, K. (1985 [1944]). The Great Transformation: the Political and Economic Origins of Our Time. Boston: Beacon Press.

Weber, M. (1934 [1904-1905]). Die protestantische Ethik und der Geist des Kapitalismus. (The Protestant Ethic and the Spirit of Capitalism) Tübingen: J. C. B. Mohr.

Weber, M. (1970 [1904-1905]). The Protestant Ethic and the Spirit of Capitalism. London: Unwin.

Weber, M. (1978 [1919-1920]). Economy and Society, Volume I. (Ed. by Guenther Roth and Claus Wittich). Berkeley, Cal.: California University Press.

Weber, M. (2013 [1919-1920]). Wirtschaft und Gesellschaft. Gesamtausgabe, Abteilung I: Schriften und Reden. Band 23. (Economy and Society. Collected Works, Part I: Writings and Speeches.) Tübingen: J. C. B. Mohr. 